\title{
PROSPECT OF DEVELOPMENT OF THE VRSNET REFERENCE STATIONS NETWORK
}

\author{
Dawid Kudas, Agnieszka Wnęk, Ihor Savchyn
}

\section{Summary}

The VRSNET is a commercial active geodetic network of reference stations deployed on Polish territory and in neighbouring countries. The paper presents a spatial analysis of locations of VRSNET permanent stations whose antennas and satellite receivers continuously record signals transmitted by Global Navigation Satellite Systems (GNSS). The study focused on delimiting the potential average range of individual stations in Poland. Spatial analyses, including Voronoi/Thiessen diagram (Dirichlet tessellations) and spatial buffers were used in the research. The study evaluated the geometry of the VRSNET network for the Real Time Kinematic (RTK) measurements that use base vectors solely from the analysed stations. Possible development of the VRSNET network through launching new reference stations was elaborated, too. The spatial analyses indicated the localisation and range of areas with an insufficient density of the VRSNET network. The locations of 16 new reference stations have been delimited on Polish territory. The VRSNET network with newly designed stations was reassessed for validation using the Voronoi/ Thiessen diagram and spatial buffers. The results were compared with the parameters for the Active Geodetic Network - European Position Determination System (ASG-EUPOS). Improved RTK measurement geometric parameters resulting from the proposed scenario of the VRSNET network development have been demonstrated. Network density can also have a positive impact on the measurement results of the Network Real Time Kinematic (NRTK).

\section{Keywords}

VRSNET • active geodesic network design $\bullet$ RTK • GNSS • Voronoi/Thiessen polygons $\bullet$ CORS

\section{Introduction}

Reference stations which continuously record Global Navigation Satellite Systems (GNSS) signals are referred to as Continuously Operating Reference Station (CORS). A minimum of 3 stable permanent reference stations are needed to establish a network. The reference stations network can be divided in regards to its size into global, continental, regional, national and local. An example of a regional network is the European Position Determination System (EUPOS), which operates the national networks covering the territorial reach of Central and Eastern European countries. In Poland, 
at national level, the Active Geodetic Network - European Position Determination System (ASG-EUPOS) [www.asgeupos.pl] is established in accordance with EUPOS standards. Also, three commercial networks the TPI NETpro, the HxGN SmartNet and the VRSNET cover the entire territory of Poland. The stations of these networks are located throughout Poland, and they include border stations working on the territory of neighbouring countries. In addition to the listed networks in Poland, there is also a local NadowskiNet network covering the area of southern Poland.

A reference stations network has a number of applications i.e. in the field of transport and logistics, positioning of vehicles, construction, location survey, inventory of construction facilities and precise control of construction machinery, geodesy and geodynamics - setting up geodetic networks, studying the Earth's rotation, performing surveying measurements. Reference station networks also provide a reference frames both at global and regional level. Continuous GNSS observations carried out at reference stations enable ionosphere and troposphere analysis [e.g. Krypiak-Gregorczyk et al. 2013]. Based on GNSS signals recorded by reference station networks, atmospheric parameters such as Zenith Total Delay (ZTD) or Precipitable Water Vapour (PW) can be measured accurately and with high resolution [e.g. Kabelk et al. 2016, Dymarska et al. 2017, Nykiel et al. 2019]. It is crucial that these parameters can be obtained regardless of weather conditions, cloud cover or precipitation, as they do not interfere with the electromagnetic waves range, at which GNSS signals are transmitted. The reference stations network can also act as a system of sensors monitoring the deformations of sites affected by mining activities [e.g. Uznański 2019] or the deformations of industrial facilities e.g. pumped-storage hydroelectricity [e.g. Savchyn and Vaskovets 2018]. Relative positioning techniques based on reference station networks are also used in precision agriculture, in the positioning and navigation systems of agricultural machinery [e.g. Czechlowski et al. 2018].

Relative GNSS measurements are run based on the reference station networks, including static and rapid static (Fast Static, Rapid Static) techniques, DGNSS (Differential GNSS) measurements, post-processing of kinematic measurements, and real-time techniques like Real Time Kinematic (RTK) and Network Real Time Kinematic (NRTK). Currently, there are several available methods of determining position through the NRTK technique: Virtual Reference Station (VRS) [Vollath et al. 2000], Master-Auxiliary Concept (MAC) [Brown et al. 2006], its modification MasterAuxiliary Corrections (MAX), individualised Master-Auxiliary Corrections (i-MAX), Pseudo-Reference Station (PRS), and German Flächenkorrekturparameter (FKP) [Takac and Zelzer 2008]. In the case of RTK measurements, it is the significant, what the distance of a mobile receiver from the base station is, as the ionospheric and tropospheric conditions change depending on the receiver's position against the reference station. Factors affecting the accuracy of RTK measurements include ionosphere errors, troposphere errors, signal obstructions and multipath, satellites geometric configuration and other errors. It is a common practice to neglect the influence of the ionosphere up to $10 \mathrm{~km}$ [e.g. Baybura et al. 2019]. However, the accuracy of RTK measurements using receiver with radio modems is limited and the best results are obtained up to 20 
$\mathrm{km}$ from the base station [Koivula et al. 2018]. The development of algorithms and measuring devices meant that real-time techniques at a distance up to $40 \mathrm{~km}$ achieve similar results in the case of RTK and NRTK measurements [Baybura et al. 2019]. It was mainly caused by equipping the receivers used for RTK measurements with GSM modems and sending corrections via the GMS network.

The distance between the reference stations forming the network is usually restricted to $100 \mathrm{~km}$ to effectively address the ambiguity resolution in GNSS measurements [e.g. Baybura et al. 2019]. The distance between stations in commercial reference networks is usually below $100 \mathrm{~km}$ [El-Mowafy 2012]. However, to ensure high accuracy of altitude, the reference network stations should be spaced by smaller distances. As noted by Koivula et al. [2018], a typical distance in reference station networks for the purposes of the NRTK measurements is $50-70 \mathrm{~km}$, which guarantees accurate and reliable positioning. In networks with larger spacing, the risk of inaccurate initialization is greater and the time needed to initialize the mobile receiver increases [Wang et al. 2010]. The position quality not only depends on the distance between stations in the reference network, but also depends on a choice of the NRTK measurement method [Koivula et al. 2018]. Choosing the right NRTK measurement method can counteract the effects of using a sparse reference stations network [e.g. Koivula et al. 2018]. Failure of a single reference station in a network does not significantly affect the NRTK measurements, as well as does not limit the development of GNSS static observations in post-processing mode [e.g. Kudas and Wnęk 2019].

Despite many applications of reference station network, there is relatively little attention paid to the study of the spatial distribution of reference stations, especially in commercial networks. Among extensive spatial analyses of reference stations localisation, following are worth mentioning, like Muzondo et al. [2015], Calka et al. [2018] and the research on the impact of reference network density on the accuracy of NRTK measurements, or Wang et al. [2010], El-Mowafy [2012] and Koivula et al. [2018]. There are also methodologies to optimize control networks covering a small area, on which regular GNSS measurements are carried out to monitor site deformation [e.g. Savchyn and Duma 2016]. Spatial analyses can be used to identify these areas of a reference network that require additional stations. In this paper, a spatial analysis of the distribution of reference stations forming the VRSNET network has been prepared, and areas lacking density have been identified. The impact of added new reference stations in the proposed areas on the spatial distribution of the VRSNET stations was also assessed as well as a comparison between the spatial distribution of the VRSNET stations and the distribution of the ASG-EUPOS stations. The ASG-EUPOS is the primary network to the VRSNET in accordance with the provisions in force in Poland.

\section{Material and methods}

The VRSNET network consists of 99 reference stations, including 88 stations in Poland and 5 in the Czech Republic, 2 in Germany, 1 in Slovakia and 3 in Ukraine (as of 10.04.2020). Reference stations are mainly equipped in Trimble NetR9 receivers and 
Trimble Zephyr Geodetic 2 antennas. VRSNET stations are located across entire Poland (Fig. 1). The VRSNET network records satellite signals transmitted by GPS, GLONASS, GALILEO and BDS. In addition, 79 reference stations of the VRSNET network in Poland have been entered to the State Geodetic and Cartographic Resource and together operate as a state network.

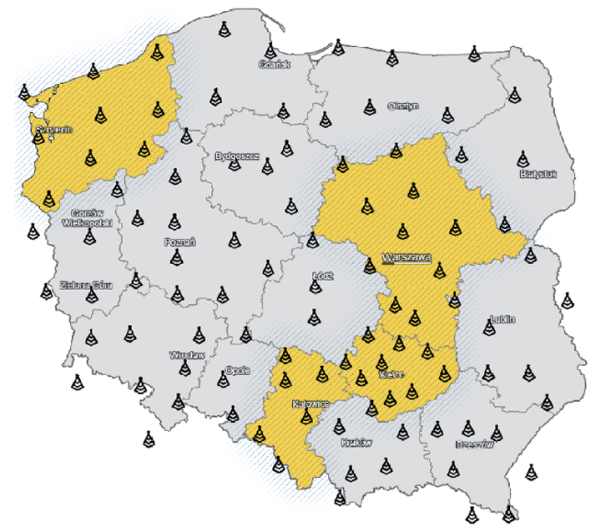

GPS, GLONASS

- GPS, GLONASS, BDS

- GPS, GLONASS, BDS GALILEO

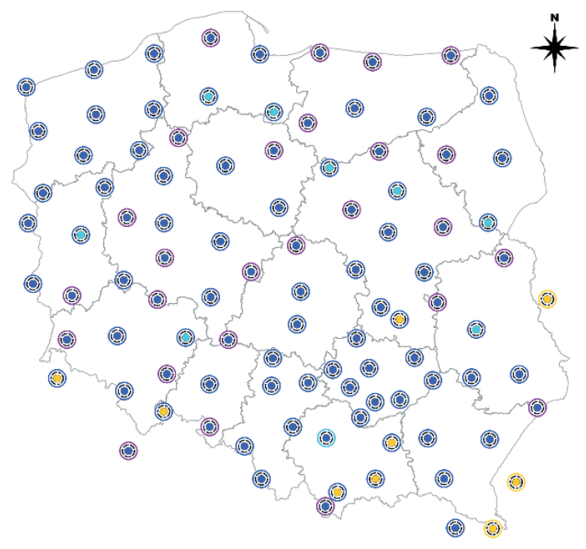

C. Trimble NetR5

() Trimble NetR9

Trimble Zephyr Geodetic 2
Trimble Zephyr Geodetic 3

Trimble GNSS Choke Ring DM

Novatel

Fig. 1. Localisation of domestic and foreign VRSNET reference stations (left) [source: www. vrsnet.pl] with equipment and tracked GNSS systems (right) [source: Authors' own study]

The VRSNET network is used as a sensor system in several scientific projects. The VRSNET network participates in the METEOPG project, under which a weather website was set up, providing weather forecasts from the high resolution version of the mesoscale model HRWRF 3.8.1/3.9.1.1 (High Resolution Weather Research and Forecasting) [www.meteopg.pl]. This project is a joint project of the Faculty of Civil and Environmental Engineering of the Gdańsk University of Technology and the TASK IT Centre. The infrastructure of the VRSNET network as a part of a cooperation with the Military University of Technology also participates in the European Plate Observing (EPOS) project [www.epos-pl.eu/] and a project focused on monitoring reference station deviations.

Access to NRTK and RTK corrections from the VRSNET network is available through NTRIPCaster, domain name siec.vrsnet.pl or IP: 178.73.5.200 for authorized users. Depending on the user's location, 6 real-time correction subnets (RTK and NRTK) are available in Poland: West Pomeranian, Świętokrzyskie, Silesian, Masovian, Greater Poland and the rest of Poland, which the user selects by connecting to the appropriate port with the domain siec.vrsnet.pl. So far, much attention has been devoted to the functioning and accuracy of positions based on corrections from VRSNET reference 
stations [e.g. Uznański 2016, 2017, Kudas et al. 2017]. At the same time the analyses of spatial relations between elements of the VRSNET network and the surface area it occupies are incoherent. The VRSNET network currently has the smallest number of reference stations among the state-owned (ASG-EUPOS) and commercial (TPINetpro, HxGN SmartNet) reference networks operating in Poland. However, in 2019 and 2020 measures have been taken to connect 1 reference station from Slovakia, 3 reference stations from Ukraine and to launch 7 additional stations in Poland that significantly improved the density of the VRSNET network.

Reference stations forming network together with accompanying infrastructure play a role of sensor system capable of receiving and registering signals transmitted by GNSS and recording meteorological parameters from the station's surroundings. Due to the above, the localisation of reference stations in the area covered by a given reference network must be regular and appropriately selected. Typically, reference stations of commercial network are located on the roofs of buildings or courtyards of public, educational and scientific institutions, and other facilities related to the geodetic industry. The analysis of the reference stations localisation by spatial analyses was conducted for the Polish network ASG-EUPOS [Calka et al. 2018]. A number of existing geospatial analyses can be employed in spatial analyses of a reference stations network, including Delaunay triangulation, Voronoi/Thiessen diagrams, nearest neighbour algorithm (NNA), spatial buffers. These methods can be used to delimit a selected area due to the location of reference stations [e.g. Muzondo et al. 2015, Calka et al. 2018] and to indicate connections between the elements of a reference network [e.g. Calka et al. 2018]. Spatial buffers are applied in spatial analyses concerning e.g. land use [e.g. Wnęk et al. 2019].

The application of the Voronoi/Thiessen diagram will allow such a division of Poland's territory that each reference stations of the analysed network will be assigned a continuous surface area of Poland. This polygon will be formed by points on the Poland's surface area that are geometrically closer to a given reference station than to other stations. Information on the history of creation and use of Voronoi/Thiessen polygons can be found in the works of Okabe et al. [2009] and Pokojski i Pokojska [2018]. The Voronoi/Thiessen diagram is a dual graph relative to Delaunay triangulation (Fig. 2), which relies on a construction based on the points of a given spatial set of triangles with the smallest variation in the length of the sides. Therefore, the circumcircle of a triangle does not contain any other points from the given set. Running perpendicular straight lines through the centres of the sides of Delaunay triangles allows indicating the spatial extent of Voronoi/Thiessen polygons (Fig. 2). Based on the Voronoi/ Thiessen diagram, it is possible to determine the range of influence of point objects on the space in which they are located. For a set of $\mathrm{P}$ reference station points belonging to a two-dimensional space of data by the formula (1):

$$
L=\left\{\left(x_{L}, y_{L}\right):\left(x_{1}, y_{1}\right),\left(x_{2}, y_{2}\right),\left(x_{3}, y_{3}\right), \ldots,\left(x_{n}, y_{n}\right)\right\}, \text { gdzie }\left(x_{L}, y_{L}\right) \in \mathbb{R}^{2}, n \in \mathbb{N}
$$

The Voronoi/Thiessen polygons area satisfies the following relationship (2): 


$$
V_{L}\left(x_{L}, y_{L}\right)=\left\{(x, y): \forall_{j \neq i} d\left((x, y),\left(x_{L, i}, y_{L, i}\right) \leq d\left((x, y),\left(x_{L, j}, y_{L, j}\right),(x, y) \in \mathbb{R}^{2}\right\}\right.\right.
$$

where:

$L$ - set of reference stations locations,

$d$ - Euclidean metric.

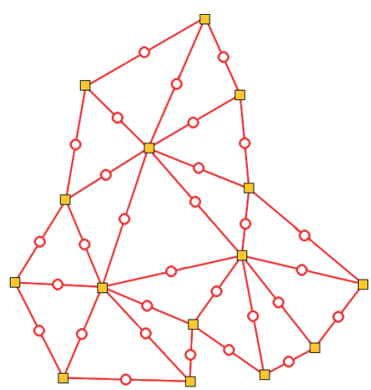

Delaunay triangulation

$\square$ Reference stations locations

$\square$ Designed reference stations locations

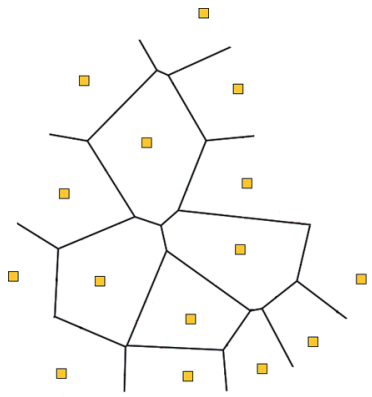

Voronoi/Thiessen polygons

- Segments

Middles of the segment

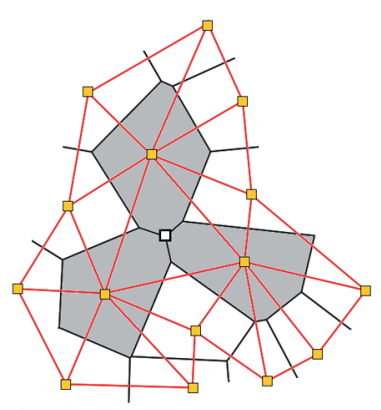

Delaunay triangulation and Voronoi/Thiessen polygons

— Bisectors

Source: Authors' own study

Fig. 2. Construction of Voronoi/Thiessen polygons based on Delaunay triangulation and determination of new reference stations optimal locations

For the Voronoi/Thiessen polygons designated by reference stations locations, the measure of shape compactness (CS) was determined [e.g. Li et al. 2013]. The CS measure ranges from 0 to 1 , with a value equal to 1 for a circular polygon and a value of approximately 0.785 for a square polygon. The CS value is given by the formula (3) [Osserman 1978]:

where:

$$
C S=40 \pi \frac{A}{P^{2}}
$$

$$
\begin{aligned}
& A \text { - polygon surface, } \\
& P \text { - polygon perimeter. }
\end{aligned}
$$

Delimitation of the area of Poland was also based on spatial buffers around the locations of reference stations. For this purpose, nine centric ring-shaped buffers with markings from 1 to 9 were generated according to the formula (4) around each reference station. The range of the buffers was selected so that it was possible to delimit the area of Poland due to RTK measurements based on the reference stations of the analysed network. The parameter for changing the zone limiting radius $(r)$ equal to 5 $\mathrm{km}$ was applied in the research. 


$$
B_{S}\left(x_{L}, y_{L}\right)=\left\{(x, y): \begin{array}{l}
s=1 \rightarrow(s-1) r<d\left((x, y),\left(x_{L}, y_{L}\right) \leq(s+1) r\right. \\
s>1 \rightarrow s r<d\left((x, y),\left(x_{L}, y_{L}\right) \leq(s+1) r\right.
\end{array}\right\}
$$

where:

$s$ - buffer number around a reference station,

$r$ - parameter for changing the radii limiting the distance zone,

$d$ - Euclidean metric.

In order to correctly assess the share of each buffer in the territory of Poland, the buffers with the same range were aggregated around the reference stations (5). In this way, 9 distance zones around the station were indicated, while the $\mathrm{DZ}_{10}$ zone was defined to supplement the total area of zones from $\mathrm{DZ}_{1}$ to $\mathrm{DZ}_{9}$ to the Polish land borders.

$$
D Z_{S}=B_{S}\left(x_{L, i}, y_{L, i}\right) \cup B_{S}\left(x_{L, j}, y_{L, j}\right) \cup \ldots \cup B_{S}\left(x_{n, k}, y_{n, k}\right)
$$

where:

$D Z_{S} \quad$ - distance zone with the number $s$,

$B_{S}\left(x_{L}, y_{L}\right)-$ buffers around a reference station with the coordinates $\left(x_{L}, y_{L}\right)$,

$n \quad-$ number of analysed reference stations.

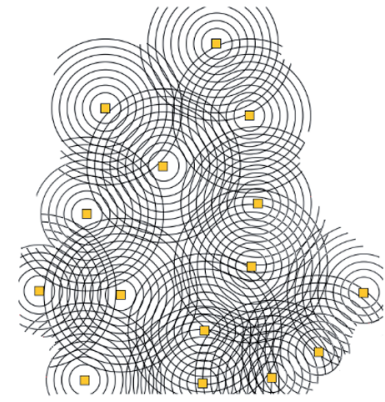

Buffors

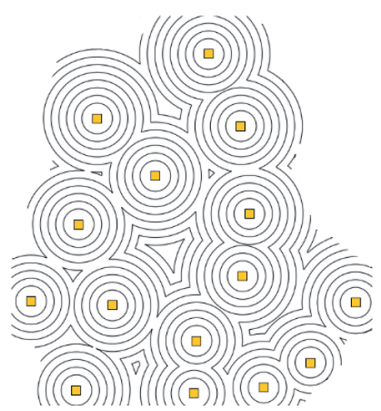

Distance zones

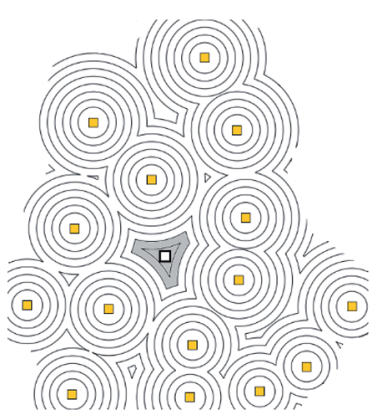

Identification distance zones $>40 \mathrm{~km}$

$\square$ Reference stations locations

B Boundaries of the dostance zone and buffors

$\square$ Designed reference stations locations

Source: Authors' own study

Fig. 3. Construction of distance zones based on spatial buffers and determination of the optimal localisation of a new reference stations

The assessment of the impact of new reference stations in the proposed locations on the spatial layout of the analysed network was assessed by re-designating the Voronoi/ Thiessen polygons and distance zones jointly for the existing and designed reference 
stations. The value of the nearest neighbour coefficient was also compared for the existing network and after the network was densified by new reference stations in the proposed locations.

Spatial analyses were performed in the QGIS 3.12.1 'București' program. QGIS is a professional GIS application proud to be built on the Free and Open Source Software (FOSS). The analyses used location coordinates of 92 stations given on the VRSNET website on 9 April 2020 [www.vrsnet.pl/], which were converted to the 1992 National projected Coordinate Reference System (EPSG 2180). The location of 6 VRSNET stations: SNIN, VOLO, SMBR, SHAZ, WITW, ZEWO were obtained by digitizing the map showing VRSNET stations available on the system's website. Digitization was performed with an average error of 5 pixels. The KR10 station was excluded from the study due to the operation of another VRSNET station in Krakow.

\section{Results}

The conducted spatial analyses with the distance zones around the existing reference stations and Voronoi/Thiessen polygons indicated areas where the VRSNET network should be densified. Therefore, the location of 16 new reference stations has been designated. If the reference stations are set in the indicated locations, the VRSNET network will be comprised of 115 stations (with the KR10 station not included in the analysis). The proposed stations should be located in the following geodesic precincts: Swierzno, Osie, Rychliki, Mrągowo, Grajewo, Hajnówka, Czyżew, M. Płock, M. Mogilno, Brzeźnio, Lubochnia, Borki, Siedliszcze, M. Nowa Sarzyna, M. Ujazd and Stryszawa. In addition, foreign stations in the border area with Lithuania and Belarus should be considered in terms of connecting them to the VRSNET network.

Delimitation of the area of Poland by 10 distance zones related to existing reference stations showed that zones with the largest share are $\mathrm{DZ}_{4}, \mathrm{DZ}_{5}, \mathrm{DZ}_{3}$ and $\mathrm{DZ}_{6}$ (Fig. 4), covering respectively $17.50 \%, 17.47 \%, 14.61 \%$ and $14.52 \%$. Zones $\mathrm{DZ}_{1}$ and $\mathrm{DZ}_{2}$, being in the closest vicinity to the existing reference stations, occupy $8.69 \%$ and $10.81 \%$, respectively. The other zones are: $\mathrm{DZ}_{7}-9.59 \%, \mathrm{DZ}_{8}-4.66 \%, \mathrm{DZ}_{9}-1.66 \%$ and $\mathrm{DZ}_{10}-0.49 \%$. Considering the limit value of the distance of the mobile receiver from the base station in RTK technique, the area of the land surface up to $40 \mathrm{~km}$ around the existing reference stations of the VRSNET network covers $93.19 \%$ of the area of Poland. However, the most favourable area for the RTK technique, i.e. an area up to $10 \mathrm{~km}$ around the existing reference stations of the VRSNET, covers $19.50 \%$ of Poland. The proposed densification of the VRSNET network will increase the share of $\mathrm{DZ}_{1-5}$ in the distance zone from reference stations in the territory of Poland at the expense of $\mathrm{DZ}_{6-10}$ zones (Fig. 4). Zone $\mathrm{DZ}_{1}$ for dense VRSNET network will account for $10.29 \%$ of Poland's area, $\mathrm{DZ}_{2}-12.80 \%, \mathrm{DZ}_{3}-17.34 \%, \mathrm{DZ}_{4}-20.46 \%$, and $\mathrm{DZ}_{5}-18.12 \%$. Thus, the area of up to $40 \mathrm{~km}$ around reference stations of the proposed dense VRSNET network would account for $98.04 \%$ of the area of Poland. In addition, the area of Poland, where the RTK measurements are performed above $40 \mathrm{~km}$ from the base station, would decrease three times. 


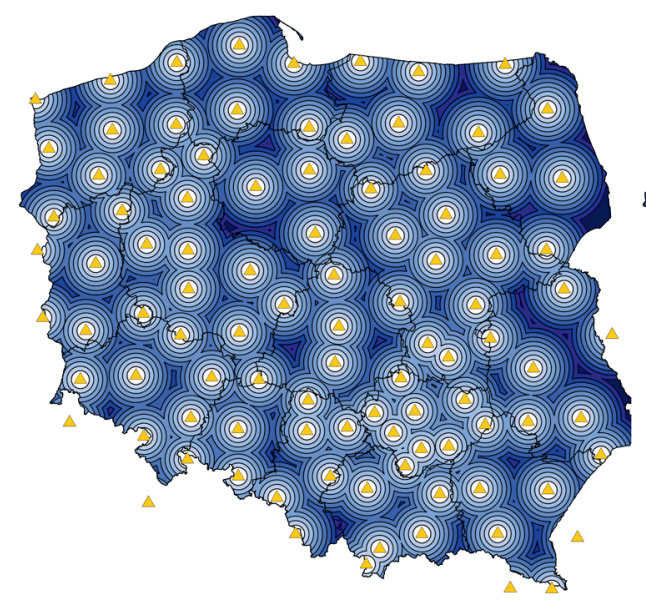

Buffer distance:

口 $0-10 \mathrm{~km}$

$\square 10-15 \mathrm{~km}$

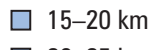

$\square$ 20-25 km $\square 25-30 \mathrm{~km}$
$\square 30-35 \mathrm{~km}$

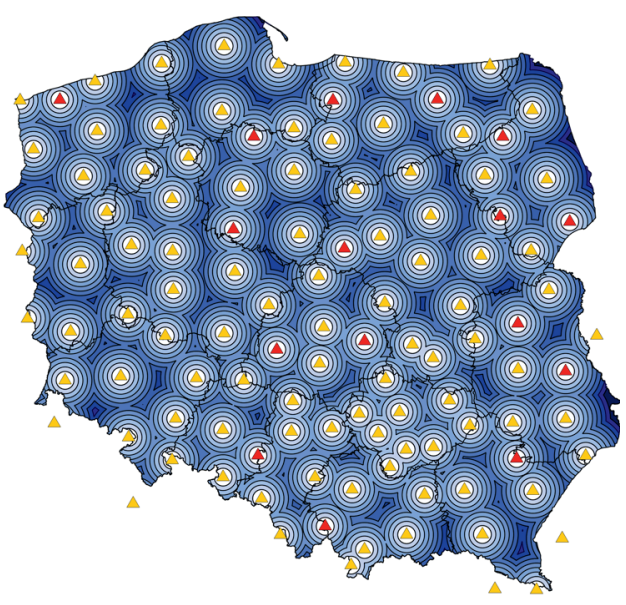

$\square$ 35-40 km

40-45 km $\square$ 45-50 km

$\square>50 \mathrm{~km}$

Source: Authors' own study

Fig. 4. Delimitation of the area of Poland for the existing VRSNET stations locations (left) and for the dense VRSNET network (right) using distance zones - the proposed locations of new stations are marked in red

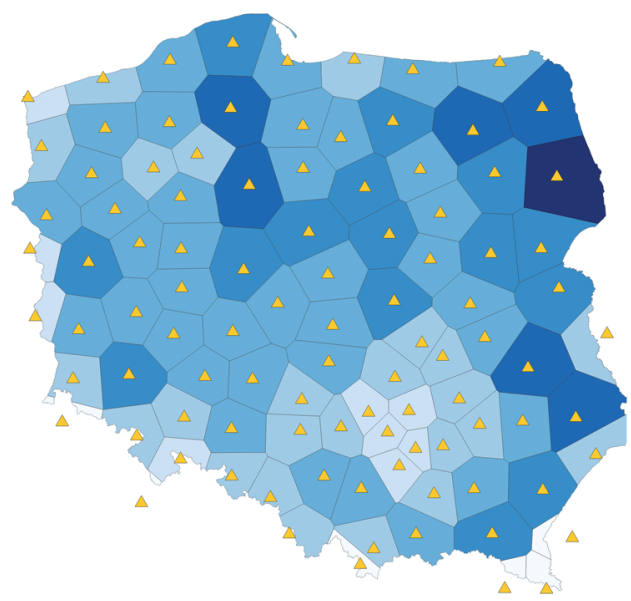

Voronoi/Thiessen polygons area:

$$
\square \quad 95-1000 \mathrm{~km}^{2}
$$

$\square \quad 1000-2000 \mathrm{~km}^{2}$

\begin{abstract}
$\square \quad 2000-3000 \mathrm{~km}^{2}$
\end{abstract}
$\square \quad 3000-4000 \mathrm{~km}^{2}$

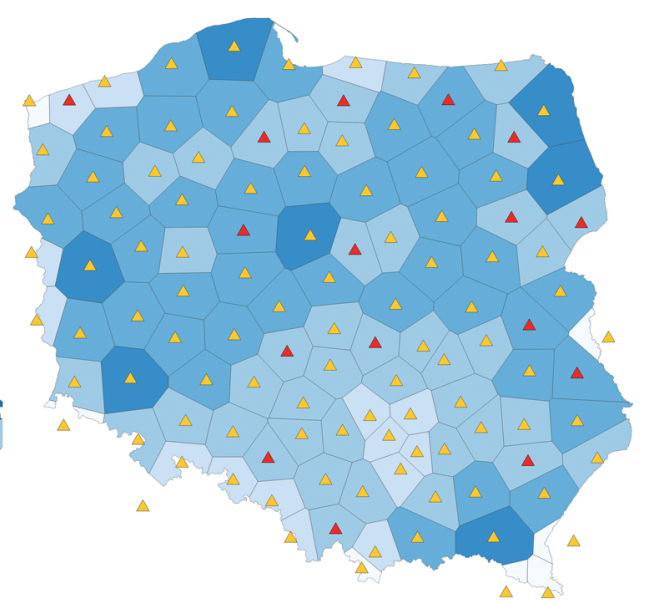

$\square \quad 4000-5000 \mathrm{~km}^{2}$

$\square \quad 5000-6000 \mathrm{~km}^{2}$

Source: Authors' own study

Fig. 5. Delimitation of the area of Poland the existing VRSNET stations locations (left) and for the dense VRSNET network (right) using Voronoi/Thiessen polygons- the proposed locations of new stations are marked in red 
Based on existing VRSNET stations, 98 Voronoi/Thiessen polygons were created in Poland (Fig. 5). The area of Voronoi/Thiessen polygons created from the existing VRSNET stations in Poland is from 1431 to $6805 \mathrm{~km} 2$. The average area, on the other hand, is 3781 $\mathrm{km} 2$, with a slightly lower median value of $3632 \mathrm{~km} 2$. The mean value of CS is 0.769 . In Poland, currently the concentration of Voronoi/Thiessen polygons with the largest spatial range can be seen in the north-east and east of Poland (Fig. 5). Based on the proposed dense VRSNET network, 114 Voronoi/Thiessen polygons would be created, the area of which would be between 95 and $4592 \mathrm{~km}^{2}$. Whereas, the average area of a Voronoi/ Thiessen polygon would reach $2741 \mathrm{~km}^{2}$, with a median value of approximately 2870 $\mathrm{km}^{2}$. The obtained average value is close to the area of Voronoi/Thiessen polygons created from the ASG-EUPOS stations, which is about $2717 \mathrm{~km}^{2}$ [Calka et al. 2017].
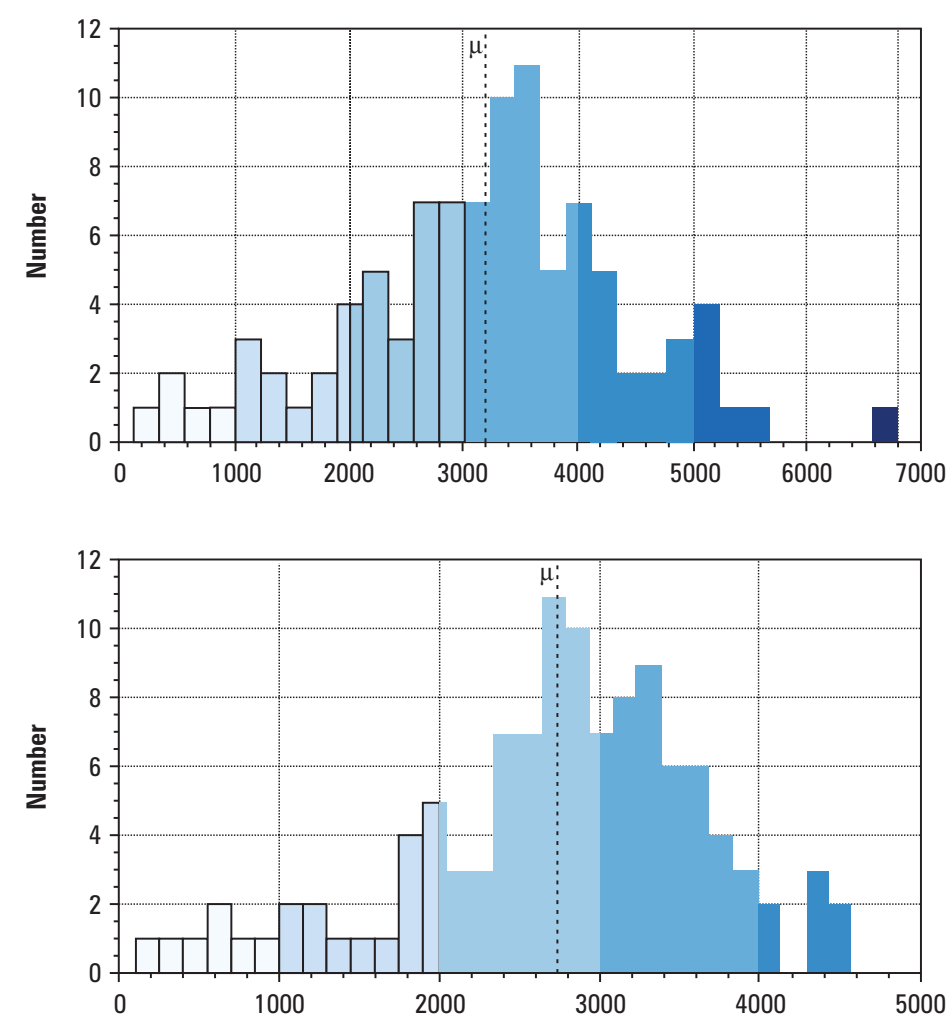

Source: Authors' own study

Fig. 6. Voronoi/Thiessen polygons surface histograms: existing VRSNET (at the top), dense VRSNET (at the bottom)

Due to the densification of the VRSNET network, Voronoi/Thiessen polygons with an area greater than $5000 \mathrm{~km}^{2}$ will not exist in Poland (Fig. 6). The CS measure calculated for the created Voronoi/Thiessen polygons reached an average value of approx. 
0.733. In the case of the ASG-EUPOS network, $50 \%$ of the Voronoi/Thiessen polygons achieved a CS value close to the square. While, in the case of a dense VRSNET network, $59 \%$ of Voronoi/Thiessen polygons have a CS measure higher than the square.

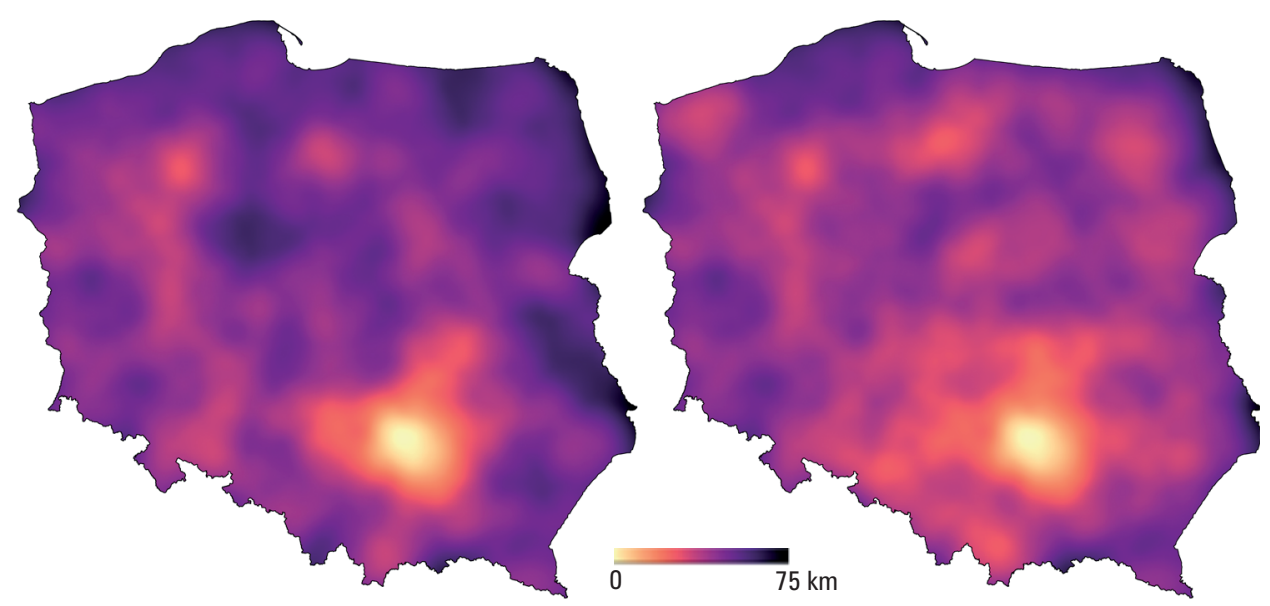

Source: Authors' own study

Fig. 7. Spatial heat map of reference station locations using a $75 \mathrm{~km}$ radius: existing VRSNET (left), dense VRSNET (right)

The spatial heat map of the set of points describing the location of reference stations with a radius of $75 \mathrm{~km}$ (average distance of stations in reference networks according to the EUPOS standard) showed a difference between the existing VRSNET network and the proposed dense network (Fig. 7).

Black areas indicating a significant distance between stations in Poland have disappeared. The improvement of the VRSNET network regularity resulting from the compaction is also shown by the NNA. The existing VRSNET network is characterized by an observed average distance of $48.808 \mathrm{~km}$, with an expected distance of about $31.631 \mathrm{~km}, \mathrm{NN}$ index has reached 1.543, and Z-Score statistics 10.284. Whereas, the proposed dense VRSNET network is characterized by an average distance of approx. $46.373 \mathrm{~km}$, with the expected distance of approx. $29.327 \mathrm{~km}$, NN index equal to 1.581 , and Z-Score statistics 11.872. Due to the average distance between reference stations, the VRSNET network is the optimal network for NRTK measurements.

\section{Conclusions}

Both Voronoi/Thiessen polygons and the distance zones based on the location of the reference stations proved to be useful for determining areas that require densification of the analysed network. If reference stations are implemented in the proposed locations, the area of sites unfavourable for RTK measurements will decrease over three 
times. While, the area of Poland favourable for RTK measurements will be $98.04 \%$. The densification of the network will also allow to significantly reduce the area of Voronoi/ Thiessen polygons created from stations. The average Voronoi/Thiessen polygon area for a densified network is $28 \%$ smaller than for the existing VRSNET network, and $21 \%$ lower for the median value. The analyses also show that the proposed density of the VRSNET network with 16 reference stations will allow it to compete in terms of spatial configuration in Poland with the state-owned ASG-EUPOS network (127 stations). It should be noted that the VRSNET network can achieve regular coverage of Poland with a smaller number of reference stations than currently operating ASG-EUPOS. However, it should also be noticed that the analysis with the use of Voronoi/Thiessen polygons and spatial buffers was carried out in two-dimensional space, disregarding local conditions and topography. Therefore, each of the proposed locations of new VRSNET stations should be subjected to individual analysis before implementation.

\section{References}

Baybura T., Tiryakioğlu İ., Uğur M.A., Solak H.İ., Şafak Ş. 2019. Examining the Accuracy of Network RTK and Long Base RTK Methods with Repetitive Measurements. Journal of Sensors. https://doi.org/10.1155/2019/3572605

Brown N., Geisler I., Troyer L. 2006. RTK Rover Performance using the Master-Auxiliary Concept. Journal of Global Positioning Systems, 5. https://doi.org/10.5081/jgps.5.1.135

Calka B., Bielecka E., Figurski M. 2017. Spatial pattern of ASG-EUPOS sites. Open Geosciences, 9(1), 613-621. https://doi.org/10.1515/geo-2017-0046

Czechlowski M., Wojciechowski T., Adamski M., Niedbała G., Piekutowska M. 2018. Application of ASG-EUPOS high precision positioning system for cereal harvester monitoring. Journal of Research and Applications in Agricultural Engineering, 63(4), 44-50.

Dymarska N., Rohm W., Sierny J., Kapłon J., Kubik T., Kryza M., Jutarski J., Gierczak J., Kosierb R. 2017. An assessment of the quality of near-real time GNSS observations as a potential data source for meteorology. Meteorology, Hydrology and Water Management, 5(1), 3-13. https://doi.org/10.26491/mhwm/65146

El-Mowafy A. 2012. Precise Real-Time Positioning Using Network RTK, Global Navigation Satellite Systems: Signal, Theory and Applications, Shuanggen Jin, IntechOpen. https://www. intechopen.com/books/global-navigation-satellite-systems-signal-theory-and-applications/ precise-real-time-positioning-using-network-rtk. https://doi.org/10.5772/29502

Grejner-Brzezinska D., Wielgosz P., Kashani I., Smith D., Spencer P., Robertson D., Mader G. 2004. An analysis of the effects of different network-based ionosphere estimation models on rover positioning accuracy. Journal of Global Positioning Systems, 3, 1-2, 115-131. https:// doi.org/10.5081/jgps.3.1.115

Kablak N., Reity O., Ştefan O., Rădulescu A.T.G.M., Rădulescu C. 2016. The Remote Monitoring of Earth's Atmosphere Based on Operative Processing GNSS Data in the UA-EUPOS/ZAKPOS Network of Active Reference Stations. Sustainability 8(4), 391. https://doi. org/10.3390/su8040391

Koivula H., Kuokkanen J., Marila S., Lahtinen S., Mattila T. 2018. Assessment of sparse GNSS network for network RTK. Journal of Geodetic Science, 8(1), 136-144. https://doi. org/10.1515/jogs-2018-0014 
Krypiak-Gregorczyk A., Wielgosz P., Gosciewski D., Paziewski J. 2013. Validation of approximation techniques for local total electron content mapping. Acta Geodynamica et Geomaterialia, 10, 3(171), 275-283. https://doi.org/10.13168/AGG.2013.0027

Kudas D., Wnęk A., Czempas T. 2017. Compatibility of RTN solutions in selected active geodetic networks. Infrastructure and Ecology of Rural Areas, II/2017, 767-781. https://doi. org/10.14597/infraeco.2017.2.2.059

Kudas D., Wnęk A. 2019a. Operation of ASG-EUPOS POZGEO sub-service in the event of failure of reference stations used in the standard solution - case study. Geomatics, Landmanagement and Landscape, 4, 59-71. http://dx.doi.org/10.15576/GLL/2019.4.59

Li W., Goodchild M.F., Church R. 2013. An efficient measure of compactness for two-dimensional shapes and its application in regionalization problems. International Journal of Geographical Information Science, 27, 6, 1227-1250. https://doi.org/10.1080/13658816.2012.7 52093

Muzondo I.F., Combrinck L., Botai J.O., Munghemezulu C. 2015. A Spatial Analysis of Global Navigation Satellite System Stations Within the Context of the African Geodetic Reference Frame. In: International Association of Geodesy Symposia, Springer International Publishing. https://doi.org/10.1007/1345_2015_199

Nykiel G., Figurski M., Baldysz Z. 2019. Analysis of GNSS sensed precipitable water vapour and tropospheric gradients during the derecho event in Poland of 11th August 2017. Journal of Atmospheric and Solar-Terrestrial Physics, 193. https://doi.org/10.1016/j. jastp.2019.105082.

Okabe A., Boots B., Sugihara K., Chiu S.N. 2009. Spatial Tessellations: Concepts and Applications of Voronoi Diagrams. John Wiley \& Sons, Chichester-New York-Weinheim-Brisbane-Singapore-Toronto.

Osserman R. 1978. Isoperimetric inequality. Bulletin of the American Mathematical Society, 84 (6), 1182-1238.

Pokojski W., Pokojska P. 2018. Voronoi diagrams - inventor, method, applications. Polish Cartographical Review, 50(3), 141-150. https://doi.org/10.2478/pcr-2018-0009

Savchyn I., Duma M. 2016. Dniester PSPP control GNSS network optimization. ISTCGCAP, 84, 84, 17-24. https://doi.org/10.23939/istcgcap2016.02.017

Savchyn I., Vaskovets S. 2018. Local geodynamics of the territory of Dniester Pumped Storage Power Plant. Acta Geodyn. Geomater., 15, 1 (189), 41-46. https://doi.org/10.13168/ AGG.2018.0002

Takac F., Zelzer O. 2008. The Relationship Between Network RTK Solutions MAC, VRS, PRS, FKP and i-MAX. In: Proceedings of the 21st International Technical Meeting of the Satellite Division of The Institute of Navigation (ION GNSS 2008), Savannah, GA, USA, 16-19 September 2008.

Uznański A. 2016. Pozycjonowanie RTN w odniesieniu do różnych sieci stacji referencyjnych w Polsce. Zeszyty Naukowo-Techniczne Stowarzyszenia Inżynierów i Techników Komunikacji Rzeczpospolitej Polskiej. Oddział w Krakowie, cz. 1.

Uznański A. 2017. Analiza porównawcza jakości pomiarów RTN nawiązanych do wszystkich sieci referencyjnych w Polsce. Zeszyty Naukowo-Techniczne Stowarzyszenia Inżynierów i Techników Komunikacji Rzeczpospolitej Polskiej, 1(112).

Uznański A. 2019. Monitoring of mining areas in relation to various reference networks. In: E3S Web Conference, 106, 01012. https://doi.org/10.1051/e3sconf/201910601012

Vollath U., Buecherl A., Landau H., Pagels C., Wagner B. 2000. Multi-base RTK positioning using Virtual Reference Stations. 13th Int. Tech. Meeting of the Satellite Div. of the U.S. Institute of Navigation, Salt Lake City, Utah, 19-22 September 2000, 123-131. 
Wang C., Feng Y., Higgins M., Cowie B. 2010. Assessment of commercial network RTK user positioning performance over long inter-station distances. Journal of Global Positioning Systems, 9(1), 78-89. https://doi.org/10.5081/jgps.9.1.78

Wnęk A., Kudas D., Halva J. 2019. Analysis of changes in land cover structure using ring-shaped polygons of evaluation, on the example of selected areas of Slovakia, Poland and the Czech Republic. Geomatics, Landmanagement and Landscape, 1, 45-56. http://dx.doi.org/10.15576/ GLL/2019.1.45

www.asgeupos.pl: ASG-EUPOS [accessed: 7.04.2020 r.]

www.epos-pl.eu: Europen Plate Observing [accessed: 7.04.2020 r.]

www.meteopg.pl [accessed: 7.04.2020 r.]

www.vrsnet.pl: VRSNET [accessed: 10.04.2020 r.]

Mgr inż. Dawid Kudas

Uniwersytet Rolniczy w Krakowie

Katedra Geodezji

30-198 Kraków, ul. Balicka 253a

e-mail: dawid.kudas@urk.edu.pl

ORCID: 0000-0003-1109-114X

Dr inż. Agnieszka Wnęk

Uniwersytet Rolniczy w Krakowie

Katedra Geodezji

30-198 Kraków, ul. Balicka 253a

e-mail: ag.wnek@urk.edu.pl

ORCID: 0000-0001-8669-2519

PhD Ihor Savchyn

Lviv Polytechnic National University

Institute of Geodesy, Ukraine

e-mail: ih.savchyn@gmail.com

ORCID: 0000-0002-5859-1515 